University of Nebraska - Lincoln

DigitalCommons@University of Nebraska - Lincoln

1977

\title{
Use of Natural Basin Wetlands by Breeding Waterfowl in North Dakota
}

Harold A. Kantrud

USGS Northern Prairie Wildlife Research Center

Robert E. Stewart

USGS Northern Prairie Wildlife Research Center

Follow this and additional works at: https://digitalcommons.unl.edu/usgsnpwrc

Part of the Other International and Area Studies Commons

Kantrud, Harold A. and Stewart, Robert E., "Use of Natural Basin Wetlands by Breeding Waterfowl in North Dakota" (1977). USGS Northern Prairie Wildlife Research Center. 179.

https://digitalcommons.unl.edu/usgsnpwrc/179

This Article is brought to you for free and open access by the US Geological Survey at DigitalCommons@University of Nebraska - Lincoln. It has been accepted for inclusion in USGS Northern Prairie Wildlife Research Center by an authorized administrator of DigitalCommons@University of Nebraska - Lincoln. 


\title{
USE OF NATURAL BASIN WETLANDS BY BREEDING WATERFOWL IN NORTH DAKOTA
}

\author{
HAROLD A. KANTRUD, U.S. Fish and Wildlife Service, Northern Prairie Wildlife Research Center, Jamestown, North Dakota \\ 58401 \\ ROBERT E. STEWART, U.S. Fish and Wildlife Service, Northern Prairie Wildlife Research Center, Jamestown, North Dakota \\ 58401
}

\begin{abstract}
Use of basin wetlands by breeding populations of 12 species of waterfowl was investigated in 1965 and during 1967-69 throughout the prairie pothole region of North Dakota. Data were obtained primarily by random sampling techniques. Of the total population occupying natural basin wetlands 55 percent occupied seasonal and 36 percent occupied semipermanent wetlands. Seasonal wetlands contained 60 percent of the population of dabbling ducks, while semipermanent wetlands supported 75 percent of the population of diving ducks. On basins with ponded water, highest concentrations of breeding pairs occurred on temporary, seasonal, and semipermanent wetlands; moderate concentrations were recorded on ephemeral, fen, and undifferentiated tillage wetlands; and low concentrations occurred on permanent and alkali wetlands. The proportion of basins that retained ponded water had a direct bearing on the value of each type of wetland to breeding waterfowl. Relative values of the more intermittent types of wetlands are greatly increased during years of ample precipitation.
\end{abstract}

J. WILDL. MANAGE. 41(2):243-253

Shallow basin wetlands in the prairie pothole region of south-central Canada and north-central United States represent the principal breeding habitats of many waterfowl species in North America. Climatic instability and natural differences in the capacity to retain ponded water cause drastic annual and seasonal variations in the distribution and number of ponds, and in the area of ponded water among various types of basins.

Densities of breeding waterfowl as related to wetland habitat were investigated in the prairie pothole region by a number of biologists, including Evans and Black (1956), Jenni (1956), Benson (1964), Jessen et al. (1964), Drewien and Springer (1969), Sauder (1969), Smith (1971), and Stoudt (1971). The results of these studies are not comparable because each investigator used his own wetland classification system or a modified version of the systems of Bach (Bach, R. N. 1950. Some general aspects of North Dakota water areas and their study. North Dakota Game and Fish Dept. 13pp. Mimeo.) or Martin et al. (1953). Moreover, most of these studies were restricted to short transects or small blocks of land. Regardless of length, roadside transects may not provide a representative sample of wetlands because of changes in wetland characteristics and densities caused by road construction. Small blocks of land usually contain too few wetlands to make meaningful comparisons of waterfowl use among wetland types.

In this paper, we report the use by breeding waterfowl of wetlands classified according to a system designed specifically for the prairie pothole region (Stewart and Kantrud 1971). About 14 percent of the glaciated prairie pothole region of central North America (Fig. 1) occurs in North Dakota. This particular area contained a yearly average of $1,619,000$ pairs of breeding ducks (27.6 pairs $/ \mathrm{km}^{2}$ ) during 1967-69 (Stewart and Kantrud 1974).

Two earlier reports (Stewart and Kantrud 1973, 1974) utilized nearly the same data in documenting population estimates of breeding waterfowl and their proportional distribution among various wetland types and biotic sections within the prairie pothole region. We hope the information on 


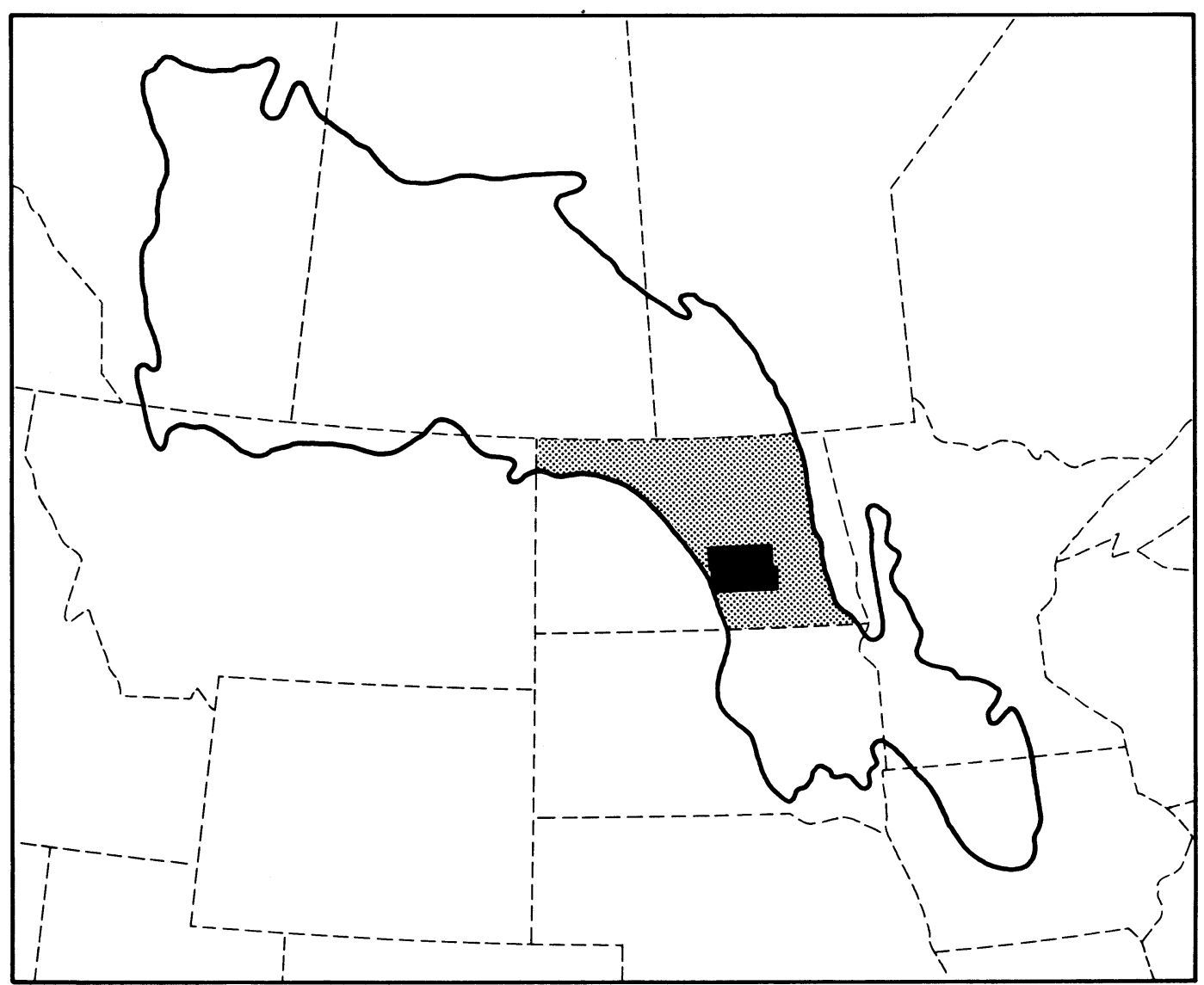

Fig. 1. Prairie pothole region of central North America, showing portion lying within North Dakota. Location of Stutsman and Kidder counties, where supplementary information was gathered, is shown in black.

pair densities contained in this paper will aid biologists to determine the effectiveness of habitat acquisition or manipulation programs and to quantify impacts to populations of breeding waterfowl caused by various private or public works projects.

We thank D. A. Davenport for the development and use of computer programs to process the data collected during 196769. D. W. Larson and C. R. Madsen assisted with the general field work in 1965, and personnel (34 in number) from the U.S. Fish and Wildlife Service, U.S. Soil Conservation Service, and North Dakota Game and Fish Department aided in the waterfowl censuses and habitat surveys in 1969. We acknowledge editorial assistance by D. H. Johnson.

\section{METHODS}

\section{Census}

Censuses were conducted during 1965 and 1967-69. In general, the proportion of wetland basins containing ponded water was about average in 1965, above average in 1967 and 1969, and below average in 1968. The investigation did not cover wet- 
land basins without ponded water in 1968 nor those on a portion of the area in 1969 . During the 1967-69 period, data were obtained from wetlands lying within sample plots selected at random from the prairie pothole region of North Dakota. This region was described and mapped in detail previously (Stewart and Kantrud 1972b, 1973). Procedures used to stratify the region, determine sample sizes, and select the sample units were described.

Sample units in 1967 and 1968 consisted of legal, 160 acre quarter sections (64.7 ha) and totaled 68 and 194 units, respectively. Cluster sampling was employed in 1969, each cluster consisting of four quarter sections that formed the corners of a square with dimensions of $2 \times 2$ miles $(3.2 \times 3.2$ $\mathrm{km}$ ); the total sample contained 332 quarter sections, grouped as 83 clusters. The several minor wetland habitats inadequately represented in the random sample were supplemented by information gathered in 1965 on discrete wetlands selected subjectively in Stutsman and Kidder counties (Fig. 1). Water depth measurements (Fig. 2) were derived from wetlands occurring on three $1.61 \mathrm{~km}^{2}$ areas in Stutsman County studied during 1961-66.

The stratified random sample surveys provided estimates of breeding duck populations and the total amount of wetland habitat. However, when data for specific wetland habitats were analyzed, the unequal representation of some habitats among the strata caused large variances. For some uncommon wetland habitats, data from both random and nonrandom studies were combined. These two conditions precluded calculation of precision estimates.

Waterfowl censuses were conducted by two observers between half hour after sunrise and half hour before sunset when sustained wind velocities did not exceed 25 $\mathrm{km} / \mathrm{hr}$. Each observer was responsible for the census of ducks on a rectangular half

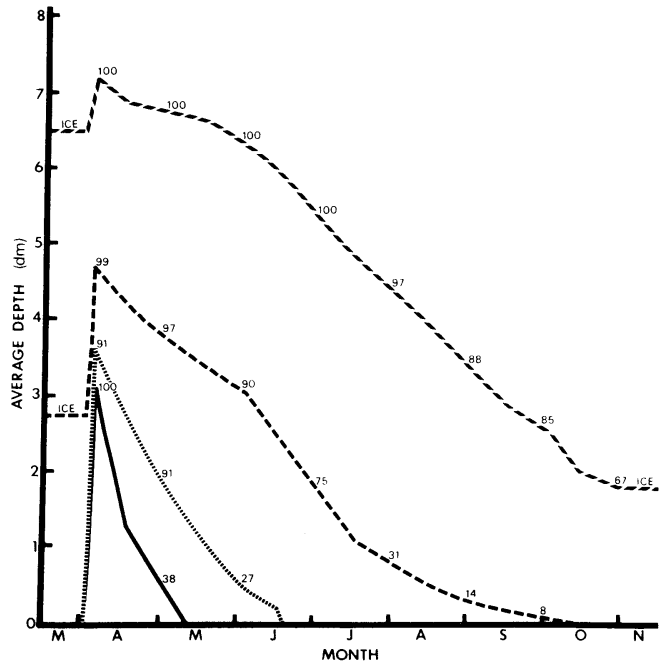

Fig. 2. Average water depth of 4 classes of basin wetlands during 1963. During a 6-year period (1961-66) average midspring water levels were higher in 2 years and lower in 3 years. Proportion of wetlands containing ponded water during the ice-free season is shown above the lines. The lines are, from top to bottom, semi permanent $(N=33)$, temporary $(N=22)$, seasonal $(N=72)$ and ephemeral $(N=8)$.

(32.4 ha) of the quarter section. Notes were kept of ducks flushed and were compared at the end of each coverage of a sample unit to avoid duplications in the counts. Censuses on large wetlands required that one observer record flushed ducks from a high vantage point while the other observer waded in a zigzag course through the wetland. During the censuses, our interpretation of segregated pairs, lone males, and mixed flocks of both sexes was in general agreement with the guidelines established by Hammond (1969). Flocks of male mallards (Anas platyrhynchos) or pintails ( $A$. acuta) containing as many as 10 individuals were occasionally observed on large wetlands during principal breeding periods. In these cases we considered each male to indicate a pair, as recommended by Dzubin (1969b).

We varied the chronology of the censuses slightly each year to compensate for variable phenological conditions. In 1965, two 
censuses were conducted. The mallard, pintail, green-winged teal (Anas crecca), shoveler (A. clypeata), American wigeon (A. americana), ring-necked duck (Aythya collaris), and canvasback (A. valisineria) were counted from 5 May to 16 May, and the gadwall (Anas strepera), blue-winged teal ( $A$. discors), redhead (Aythya americana), lesser scaup (A. affinis), and ruddy duck (Oxyura jamaicensis) were counted from 7 June to 24 June. During 1967-68, sample units were covered once or twice during the breeding season. Single coverage was restricted to those sample units covered during the overlapping period of early-, mid-, and late-nesting species. The mallard and pintail, both early-nesting species, were censused from 24 April to 7 June 1967 and from 23 April to 7 June 1968; mid-nesting species, including the gadwall, green-winged teal, blue-winged teal, shoveler, American wigeon, ring-necked duck, and canvasback were censused from 14 May to 10 July 1967 and from 15 May to 15 July 1968; and latenesting species, including the redhead, lesser scaup, and ruddy duck were censused from 22 May to 19 July 1967 and from 20 May to 23 July 1968. In 1969, because of the limited time available for cooperation by other investigators, a single census was conducted during the overlapping portion of the principal breeding periods for groups of early-, mid-, and late-nesting species; this composite period extended from 20 May to 10 June.

Data are not included for the cinnamon teal (Anas cyanoptera) and wood duck (Aix sponsa), since these species were represented in the count totals by fewer than 10 pairs. Other relatively rare breeding waterfowl including the Canada goose (Branta canadensis), common goldeneye (Bucephala clangula), bufflehead (B. albeola), and hooded merganser (Lophodytes cucullatus) were not recorded on the study areas.

\section{Wetland Classes}

The seven classes of natural-basin wetlands referred to in this report were previously described in detail (Stewart and Kantrud 1971). In this classification, five classes were distinguished on the basis of water permanence (degree of retention of ponded water) as indicated by the vegetative zone occupying the central or deepest part of the wetland basin. These classes are ephemeral, temporary, seasonal, semipermanent, and permanent. Other classes included alkali, characterized by the intermittent occurrence of shallow, highly saline surface water, and fen, recognized by a characteristic zone of vegetation that developed on areas containing surficial exposures of alkaline groundwater.

In North Dakota, many ephemeral, temporary, and seasonal wetlands were tilled for agricultural purposes. Cultivation of bottom soils of ephemeral wetlands during dry periods frequently resulted in soil movement and siltation that virtually eliminated these wetlands. We often could not assign tilled wetlands to a particular class because indicator plant species were not present. Such wetlands were called undifferentiated tillage ponds.

The density of wetlands per square kilometer was highest for undifferentiated tillage ponds (12.7). Average densities for the prevalent differentiated classes of wetlands were: ephemeral-2.5, temporary2.9 , seasonal-5.6, and semipermanent-0.8. Densities were also determined, with less accuracy, for those classes that are comparatively uncommon: permanent- 0.023 , alkali-0.023, and fen-0.015.

Average size (in ha) of basin wetlands varied as follows (figures in parentheses indicate number of wetlands in sample): ephemeral-0.04 (272), temporary-0.25 (356), seasonal-1.15 (782), semipermanent-9.34 (151), undifferentiated tillage 
Table 1. Proportional distribution (\%) of breeding duck pairs on basin wetlands, derived from wetlands occurring on sample plots censused during 1967-69.

\begin{tabular}{|c|c|c|c|c|c|c|c|c|}
\hline \multirow[b]{2}{*}{ Species $^{a}$} & \multicolumn{8}{|c|}{ Wetland type } \\
\hline & Ephemeral & Temporary & Seasonal & $\begin{array}{c}\text { Semi- } \\
\text { permanent }\end{array}$ & Permanent & Alkali & Fen & $\begin{array}{c}\text { Undifferentiated } \\
\text { tillage }\end{array}$ \\
\hline Dabbling ducks & & & & & & & & \\
\hline Mallard (811) & & 4.2 & 59.1 & 29.5 & 0.6 & 0.6 & & 6.0 \\
\hline Gadwall (746) & & 3.6 & 54.6 & 35.4 & 2.0 & 0.4 & & 4.0 \\
\hline Pintail (1013) & 0.1 & 4.1 & 61.7 & 22.4 & 0.9 & 0.3 & 0.1 & 10.4 \\
\hline $\begin{array}{l}\text { Green-winged } \\
\text { teal }(214)\end{array}$ & & & & & & & & \\
\hline $\begin{array}{l}\text { teal (214) } \\
\text { Blue-winged }\end{array}$ & & 1.4 & 64.0 & 22.0 & 5.6 & & & 7.0 \\
\hline teal $(2089)$ & $\mathrm{T}^{\mathrm{b}}$ & 2.7 & 61.2 & 31.2 & 2.5 & 0.3 & & 2.0 \\
\hline Shoveler (608) & & 3.0 & 59.2 & 33.1 & 0.3 & & & 4.4 \\
\hline $\begin{array}{l}\text { American wigeon } \\
(86)\end{array}$ & & 3.5 & 61.6 & 25.6 & & 1.2 & & 8.1 \\
\hline Diving ducks & & & & & & & & \\
\hline Redhead (326) & & & 22.1 & 76.4 & 0.6 & & & 0.9 \\
\hline $\begin{array}{l}\text { Ring-necked } \\
\text { duck (33) }\end{array}$ & & & 21.2 & 69.7 & 6.1 & & & 3.0 \\
\hline Canvasback (92) & & & 18.5 & 78.3 & 3.3 & & & \\
\hline Lesser scaup (74) & & & 37.8 & 52.7 & 5.4 & & 2.7 & 1.4 \\
\hline Ruddy duck (297) & & & 13.1 & 78.5 & 8.1 & & & 0.3 \\
\hline $\begin{array}{l}\text { Total dabbling ducks } \\
\text { (5567) } \\
\text { Total diving ducks }\end{array}$ & s & 3.3 & 60.0 & 29.7 & 1.7 & 0.3 & $\mathrm{~T}$ & 4.9 \\
\hline$(822)$ & & & 19.8 & 74.9 & 4.3 & & 0.2 & 0.7 \\
\hline Total ducks (6389) & $\mathrm{T}$ & 2.9 & 54.8 & 35.5 & 2.0 & 0.3 & $\mathrm{~T}$ & 4.4 \\
\hline
\end{tabular}

${ }^{a}$ Numbers in parentheses indicate total number of pairs in sample.

b Indicates $<0.05 \%$.

wetlands $-0.21 \quad(598)$, permanent -32.92 (21), alkali-48.04 (11), and fen-3.63 (11).

Out of the total area of ponded water during the peak breeding period for earlynesting ducks in $1967-69,44$ percent was in seasonal wetlands, 36 percent was in semipermanent wetlands, and 0.1 percent in ephemeral, 2 percent in temporary, 5 percent in permanent, 7 percent in alkali, 0.2 percent in fen, and 6 percent in undifferentiated tillage wetlands.

\section{RESULTS}

\section{Distribution of Breeding Ducks}

A previous report (Stewart and Kantrud 1973) indicated that, in the prairie pothole region of North Dakota, during 1967-69, about 84 percent of the pairs of breeding ducks occurred on natural-basin wetlands, 6 percent were on streams and oxbows, and 10 percent occupied various manmade wetlands.

Out of the total breeding population occurring on natural-basin wetlands 55 percent was on seasonal, 36 percent on semipermanent, 2.9 percent on temporary, 2 percent on permanent, 0.3 percent on alkali, and 4.4 percent on undifferentiated tillage wetlands (Table 1). Noticeable differences in the use of basin wetlands by the two ecological groups of species-dabblers and divers-were apparent: while a majority $(60 \%)$ of the dabbling duck population occupied seasonal wetlands, a vast majority (75\%) of the diving duck population occupied semipermanent wetlands. 
Table 2. Density (pairs $/ \mathrm{km}^{2}$ of wetland) of breeding ducks on wetlands containing ponded water.

\begin{tabular}{|c|c|c|c|c|c|c|c|c|}
\hline \multirow[b]{2}{*}{ Species } & \multicolumn{8}{|c|}{ Wetland type } \\
\hline & Ephemerala & Temporary & Seasonala $^{a}$ & $\begin{array}{c}\text { Semi- } \\
\text { permanent }^{\mathrm{a}}\end{array}$ & Permanent ${ }^{\mathrm{b}}$ & Alkalib & $\mathrm{Fen}^{\mathrm{b}}$ & $\begin{array}{c}\text { Undifferentiated } \\
\text { tillage }^{a}\end{array}$ \\
\hline \multicolumn{9}{|l|}{ Dabbling ducks } \\
\hline Mallard & & 66.7 & 44.9 & 28.6 & 4.3 & 1.5 & 27.3 & 29.5 \\
\hline Gadwall & & 54.3 & 38.8 & 29.5 & 7.9 & 13.4 & 17.6 & 21.1 \\
\hline Pintail & 49.2 & 82.4 & 58.6 & 27.0 & 3.6 & 6.8 & 24.8 & 63.3 \\
\hline $\begin{array}{l}\text { Green-winged } \\
\text { teal }\end{array}$ & & 6.0 & 13.1 & 5.2 & 17 & 06 & & 10.5 \\
\hline Blue-winged & & & & & & & & \\
\hline teal & 137.7 & 112.6 & 122.4 & 73.7 & 14.5 & 5.1 & 42.7 & 29.5 \\
\hline Shoveler & & 36.2 & 34.4 & 22.7 & 1.7 & 7.8 & 12.6 & 34.4 \\
\hline $\begin{array}{c}\text { American } \\
\text { wigeon }\end{array}$ & & 6.0 & 5.0 & 2.4 & 2.0 & 3.2 & & 4.9 \\
\hline \multicolumn{9}{|l|}{ Diving ducks } \\
\hline $\begin{array}{l}\text { Redhead } \\
\text { Ring-necked }\end{array}$ & & & 7.4 & 29.6 & 3.3 & 0.4 & 4.9 & 3.7 \\
\hline duck & & & 0.7 & 2.6 & 0.9 & 0.2 & & 0.7 \\
\hline Canvasback & & & 1.6 & 8.1 & 2.2 & 0.2 & & \\
\hline Lesser scaup & & & 2.9 & 4.7 & 6.1 & 1.3 & 4.9 & 1.2 \\
\hline Ruddy duck & & & 4.0 & 28.2 & 4.8 & & 17.2 & 1.2 \\
\hline \multicolumn{9}{|c|}{ Total } \\
\hline Total diving ducl & & & 16.6 & 73.2 & 17.2 & 2.1 & 27.0 & 6.8 \\
\hline \multicolumn{9}{|c|}{$\begin{array}{l}\text { Area }\left(\mathrm{km}^{2}\right) \text { of habitat } \\
\text { during breeding }\end{array}$} \\
\hline Min. & 0.0007 & 0.449 & 9.66 & 7.70 & 6.91 & 5.28 & 0.398 & 0.82 \\
\hline Max. & 0.0203 & 0.509 & 10.65 & 9.03 & 6.99 & 5.28 & 0.409 & 1.66 \\
\hline
\end{tabular}

a Data from random plots studied 1967-69.

b Data from 1965 on subjectively selected wetlands added to $1967-69$ results.

\section{Densities of Breeding Pairs}

Waterfowl use of wetlands was restricted almost entirely to those basins that contained ponded water. Annual variations in the number of basins with ponded water was positively correlated with changes in breeding waterfowl populations in many areas of the prairie pothole region (Evans and Black 1956; Jenni 1956; Salyer 1962; Rogers 1964; Drewien and Springer 1969; Stoudt 1969, 1971; Schroeder 1971; Smith 1971; Stewart and Kantrud 1974).

The value of each wetland type as related to habitat preferences is expressed as pairs per square kilometer of basins with ponded water (Table 2). High densities were found to be characteristic of both major classes of basin wetlands. For total ducks, the density was 27 percent higher on seasonal than on semipermanent wetlands. The composition of duck species also differed markedly. The prevalent species with respect to density in decreasing order were the blue-winged teal, pintail, mallard, gadwall, and shoveler on seasonal wetlands; and the blue-winged teal, redhead, gadwall, mallard, ruddy duck, pintail, and shoveler on semipermanent wetlands. The habitat affinities of dabbling ducks and diving ducks were in sharp contrast. Comparative data for seasonal and semipermanent wetlands showed that the density of dabbling ducks was about 68 percent higher on seasonal wetlands, whereas the density of diving ducks was 341 percent higher on semipermanent wetlands. 
Several other wetland types were of considerable importance, particularly for dabbling ducks. Temporary wetlands supported highest densities of dabbling ducks; principal species in decreasing order of density, included the blue-winged teal, pintail, mallard, gadwall, and shoveler-a composition the same as that of seasonal wetlands. Rather high densities also were recorded for ephemeral, fen, and undifferentiated tillage wetlands. Predominant species on these wetlands, listed in decreasing order of density, were the blue-winged teal and pintail on ephemeral wetlands; the bluewinged teal, mallard, and pintail on fens; and the pintail, shoveler, mallard, bluewinged teal, and gadwall on undifferentiated tillage wetlands. Comparatively low densities of breeding waterfowl were recorded for permanent and alkali wetlands.

The more favorable habitats for each species are also shown in Table 2. Densities of the ubiquitous blue-winged teal were especially high on ephemeral, temporary, and seasonal wetlands. Mallards and gadwalls were in highest densities on temporary and seasonal wetlands. The higher concentrations of the pintail, green-winged teal, shoveler, and American wigeon occurred on temporary, seasonal, and undifferentiated tillage wetlands. Most of the diving duck species, including the redhead, ring-necked duck, canvasback, and ruddy duck were well represented only on semipermanent wetlands. The greater densities of the lesser scaup, however, were found on permanent and fen wetlands as well as on semipermanent wetlands.

\section{Relationship of Water Retention to Pair Densities}

Since waterfowl were attracted only to those basins with ponded water, it follows that the proportion of basins with ponded water had a direct bearing on the value or usefulness of each type of basin wetland to waterfowl. This was not taken into account in previous evaluations (Table 2), because they were based entirely on average densities of breeding waterfowl on basins with ponded water. A more realistic approach in appraising the value of each wetland type was to calculate the average density of breeding waterfowl occurring on all basins of each type without regard to the presence or absence of ponded water. For most wetland types, densities calculated in this manner differed greatly from one year to the next because the proportions of basins with ponded water are so changeable.

In general, the value of the more intermittent types of basin wetlands to breeding waterfowl greatly increased during years with ample precipitation and decreased during drought years. These intermittent types include ephemeral, temporary, seasonal, alkali, and undifferentiated tillage wetlands. To a much lesser degree, these trends were also apparent for semipermanent and fen wetlands. Permanent wetlands differed from other types in that densities of breeding pairs normally remained fairly constant every year, regardless of changing climatic conditions.

Information concerning the use of the more common types of basin wetlands during years with ample (above average) precipitation is included in Table 3. These densities (pairs $/ \mathrm{km}^{2}$ ) of breeding waterfowl were calculated from combined population data obtained in 1967 and 1969 on basins with or without ponded water. The data clearly show that densities of total ducks were highest on seasonal wetlands and fairly high on semipermanent wetlands, only moderate on temporary wetlands, rather low on undifferentiated tillage wetlands, and very low on ephemeral wetlands. Though seasonal wetlands were the principal habitat utilized by all species of dab- 
bling ducks, semipermanent wetlands also supported moderate numbers, particularly of mallard, gadwall, pintail, blue-winged teal, and shoveler. Appreciable use of undifferentiated tillage wetlands by pintails and mallards also was recorded. Semipermanent wetlands were of paramount importance for all species of diving ducks. Rather limited use by redheads and ruddy ducks occurred on seasonal wetlands.

\section{DISCUSSION}

The combined effects of many variable ecological factors were reflected by differences in the distribution and density of breeding waterfowl among the types of basin wetlands. Perhaps the most important of these factors was water permanence, the length of time that ponded water was maintained in wetland basins. Water permanence had a direct bearing on the species composition and prevalence of wetland plant communities so important to waterfowl habitat (Stewart and Kantrud 1971). The fertility of ponded water in several types of basin wetlands was also determined in part by water permanence, because nutrients bound in organic matter were released through oxidation of bottom soils when wetlands went dry. In response to increased water fertility, greater populations of invertebrate food organisms appeared, making the ponds more attractive to breeding waterfowl (Moyle 1961). Salinity was important in some types of wetlands, sometimes closely correlated with differences in vegetation (Stewart and Kantrud 1972a). It may influence the occurrence and abundance of invertebrates (Serie and Swanson 1976, Swanson et al. 1974). The attractiveness of some wetlands to waterfowl may be related to annual changes in the ratio of emergent vegetation to open water, which have been attributed to fluctuations in water depth (Stewart and Kantrud 1971).
Table 3. Density (pairs $/ \mathrm{km}^{2}$ of wetland) of breeding ducks on wetlands without regard to presence or absence of ponded water. Data from sample plots studied in 1967 and 1969.

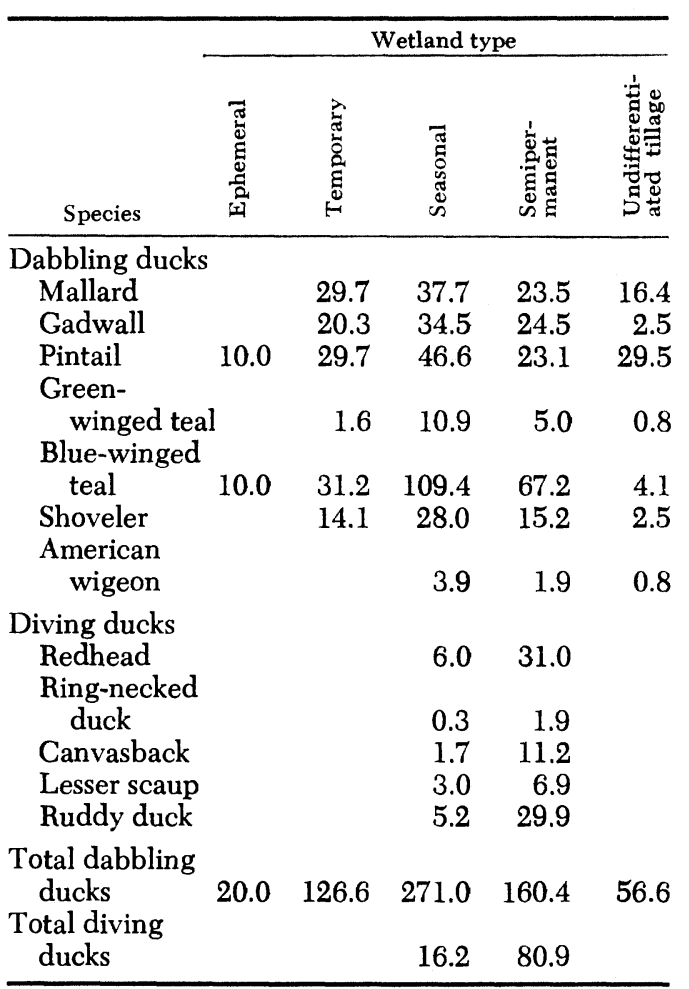

Water depth and temperature affected the abundance and availability of waterfowl foods (Krapu 1974, Swanson et al. 1974). Other environmental variables that undoubtedly influenced breeding waterfowl included wetland size, land use, and the composition of local wetland complexes, particularly in regard to the number, size and types of basin wetlands. In addition, observed differences in utilization of wetlands by breeding ducks may be partly related to extrinsic factors such as population size, mortality, and homing rates (Dzubin 1969a, Dzubin and Gollop 1972).

Seasonal wetlands undoubtedly provided the greatest abundance of high-quality wetland habitat for breeding ducks during years 
of average or above-average water. In such years nearly all seasonal wetlands retained ponded water throughout the spring and early summer and their value to breeding waterfowl was maximized. During years of below-average water conditions the value of seasonal wetlands may be reduced greatly. The moderately shallow central and peripheral vegetative zones of seasonal wetlands probably were the main feeding areas for breeding dabbling ducks during most years. The nutrient availability remained high because seasonal wetlands were usually dry by late summer, resulting in the annual oxidation of organic matter which would otherwise remain stable (Swanson et al. 1974). Seasonal wetlands were very numerous and widely distributed and thus provided isolation for pairs during courtship as well as waiting sites for males near their nesting hens. The dense stands of shallow-marsh emergents including burreed (Sparganium eurycarpum), slough sedge (Carex atherodes), and whitetop (Scolochloa festucacea) were also utilized as nesting sites by some diving ducks, especially during wet years (Stewart 1975, Stoudt in prep.).

Semipermanent wetlands comprised the principal breeding habitat for diving ducks throughout the North Dakota portion of the prairie pothole region. During years with below-average water, they often served as the principal breeding habitat for dabbling ducks as well (Stewart and Kantrud 1973). They normally retained ponded water throughout the breeding season. For this reason, their value for breeding waterfowl remained relatively stable except during very dry years. Diving ducks normally spent the greater part of their time on the relatively deep open-water areas where luxuriant beds of submerged aquatic plants occurred (Bartonek and Hickey 1969, Rogers and Korschgen 1966). Stands of tall, coarse emergent plants such as common cattail (Typha latifolia) and hardstem bulrush (Scirpus acutus), furnished the over-water nesting cover that was required by diving ducks. Shallow, peripheral areas were used as feeding and resting sites by dabbling ducks. Although semipermanent wetlands were not as abundant as seasonal wetlands, they were relatively large; as a consequence, their long shorelines might be occupied simultaneously by numerous breeding pairs.

Temporary wetlands containing ponded water were unique in that they supported greater densities of breeding dabbling ducks than any other wetland type. This was indicative of their fertility as reflected by the abundance and availability of invertebrate food organisms. Temporary ponds were usually the first to develop an invertebrate population each spring due to the rapid warming of the shallow water which is characteristic (Swanson et al. 1974). Following this initial spring period, the use by waterfowl of temporary wetlands was generally quite low because ponded water was not maintained for more than 2 or 3 weeks. Although temporary ponds were numerous, the proportion of the total basin wetland area they contributed was low because of their small average size.

Undifferentiated tillage wetlands are cultivated because of a low degree of water permanence, and, like temporary wetlands, their use by breeding ducks was low. They comprised about one-fourth of the total area of basin wetlands (Stewart and Kantrud 1973). However, the amount of suitable waterfowl habitat provided was small because of the rapid loss of ponded water. Water volume in ponds located in crop fields was often reduced by heavy siltation from adjacent uplands. In spring, the value of tillage wetlands to breeding waterfowl was dependent in part on the presence of stubble, 
dead weeds, and crop residue. Waterfowl use of tilled wetlands devoid of old growth was much reduced because these ponds lacked the organic substrate that is vital for production of an abundant invertebrate fauna. Krapu (1974) showed that frequently tilled wetlands did not produce sufficient invertebrate proteins to supply the needs of pintail hens during egg-laying. Tillage wetlands containing stubble or other dead vegetative debris were capable of producing large populations of invertebrates and thus attracted breeding dabbling ducks, at least temporarily.

Ephemeral, permanent, alkali, and fen wetlands were of minor importance. Their combined basins were occupied by only 2.3 percent of the total population of breeding waterfowl. Ephemeral wetlands usually held ponded water for only a few days following snow-melt or for a few hours following heavy summer rainstorms. At the opposite extreme, permanent wetlands provided a constant source of water with stable levels, but their value to breeding waterfowl was low. This poor utilization probably resulted from a combination of factors including excessive water depth, low rates of nutrient recycling, competition for invertebrates by minnows (Swanson and Nelson 1970 ), and the scarcity of vegetated, shallow-water feeding areas because of steep, rocky shorelines or severe wave action. Alkali wetlands often contained shallow, highly fertile expanses of surface water that supported abundant, easily accessible invertebrates for food. However, because their shorelines were largely devoid of emergent vegetation significant use by breeding pairs was probably limited by lack of protective cover. Fens supported moderate densities of breeding ducks, but their overall value was insignificant owing to their scarcity.

The relative values of various types of basin wetlands, as specified in this report, apply only to breeding pairs of ducks. Evaluations based on use by duck broods and migrant waterfowl, and on use by breeding and migrating populations of other marsh or aquatic birds may differ greatly.

\section{LITERATURE CITED}

Bartonek, J. C., and J. J. Hickey. 1969. Food habits of canvasbacks, redheads, and lesser scaup in Manitoba. Condor 71(3):280-290.

Benson, R. I. 1964. A study of duck nesting and production as related to land use in Pope County, Minnesota. Minnesota Dept. Conserv. Div. Game and Fish Tech. Bull. 8(Sect. IV): 107-126.

Drewien, R. C., ANd P. F. Springer. 1969. Ecological relationships of breeding blue-winged teal to prairie potholes. Pages $102-115$ in Saskatoon wetlands seminar. Can. Wildl. Serv. Rep. Ser. 6.

Dzubin, A. 1969a. Comments on carrying capacity of small ponds for ducks and possible effects of density on mallard production. Pages 138-160 in Saskatoon wetlands seminar. Can. Wildl. Serv. Rep. Ser. 6.

1969b. Assessing breeding populations of ducks by ground counts. Pages 178-230 in Saskatoon wetlands seminar. Can. Wildl. Serv. Rep. Ser. 6.

$\longrightarrow$, AND J. B. Gollop. 1972. Aspects of mallard breeding ecology in Canadian parkland and grassland. Pages 113-152 in Population ecology of migratory birds. U.S. Bur. Sport Fish. Wildl. Wildl. Res. Rep. 2.

Evans, C. D., AND K. E. BLACK. 1956. Duck production studies on the prairie potholes of South Dakota. U.S. Fish WildI. Serv. Spec. Sci. Rep. Wildl. 32. $59 \mathrm{pp}$.

HAMmond, M. C. 1969. Notes on conducting waterfowl breeding population surveys in the north central states. Pages 238-254 in Saskatoon wetlands seminar. Can. Wildl. Serv. Rep. Ser. 6.

JENNI, D. A. 1956. Pothole water levels in relation to waterfowl breeding populations and production. M.S. Thesis. Utah State Univ., Logan. 55pp.

Jessen, R. L., J. P. Lindmeier, and R. E. Farmes. 1964. A study of duck nesting and production as related to land use in Mahnomen County, Minnesota. Minnesota Dept. Conserv. Div. Game and Fish Tech. Bull. 8(Sect. II): $26-85$.

KraPU, G. L. 1974. Feeding ecology of Pintail hens during reproduction. Auk 91 (2):278-290.

Martin, A. C., N. Hotchkiss, F. M. Uhler, and W. S. Bourn. 1953. Classification of wet- 
lands of the United States. U.S. Fish Wildl. Serv. Spec. Sci. Rep. Wildl. 20. 14pp.

MoyLe, J. B. 1961. Aquatic invertebrates as related to larger water plants and waterfowl. Minnesota Conserv. Dept. Invest. Rep. 233. 24pp.

Rogers, J. P., AND L. J. Korschgen. 1966. Foods of lesser scaups on breeding, migration, and wintering areas. J. Wildl. Manage. 30(2):258264.

SAUDER, D. W. 1969. An evaluation of the roadside technique for censusing breeding waterfowl. M.S. Thesis. South Dakota State Univ., Brookings. 60pp.

Serie, J. R., ANd G. A. Swanson. 1976. Feeding ecology of breeding gadwalls on saline wetlands. J. Wildl. Manage. 40(1):69-81.

Sмiтн, A. G. 1971. Ecological factors affecting waterfowl production in the Alberta parklands. U.S. Bur. Sport Fish. Wildl. Resour. Publ. 98. 49pp.

Stewart, R. E. 1975. Breeding birds of North Dakota. Tri-college Center for Environmental Studies, North Dakota State Univ., Fargo, North Dakota. 295pp.

, AND H. A. Kantrud. 1971. Classification of natural ponds and lakes in the glaciated prairie region. U.S. Bur. Sport Fish. Wildl. Resour. Publ. 92. 57pp.

$\longrightarrow$, AND $-1972 a$. Vegetation of prairie potholes, North Dakota, in relation to quality of water and other environmental factors. U.S. Geol. Surv. Prof. Pap. 585-D. 36pp.

$\longrightarrow$, AND — 1972 $b$. Population estimates of breeding birds in North Dakota. Auk 89 (4) :766-788.

$\longrightarrow$, AND —. 1973. Ecological distribution of breeding waterfowl populations in North Dakota. J. Wildl. Manage. 37 (1):39-50.

$\longrightarrow$, AND —. 1974. Breeding waterfowl populations in the prairie pothole region of North Dakota. Condor 76(1):70-79.

Stоuдт, J. H. 1971. Ecological factors affecting waterfowl production in the Saskatchewan parklands. U.S. Bur. Sport Fish. Wildl. Resour. Publ. 99. 58pp.

- (in prep.). Habitat relationships of breeding canvasbacks on a Manitoba study area. U.S. Fish Wildl. Serv. Resour. Publ.

Swanson, G. A., And H. K. Nelson. 1970. Potential influence of fish rearing programs on waterfowl breeding habitat. Pages 65-71 in Edw. Schneberger, ed. A symposium on the management of midwestern winterkill lakes. Am. Fish. Soc. N. Central Div.

-, M. I. Meyer, and J. R. Serie. 1974. Feeding ecology of breeding blue-winged teals. J. Wildl. Manage. 38(3):396-407.

Received 19 April 1976.

Accepted 27 January 1977. 